\title{
Ephrin Type-A Receptor 1
}

National Cancer Institute

\section{Source}

National Cancer Institute. Ephrin Type-A Receptor 1. NCI Thesaurus. Code C18509.

Ephrin type-A receptor 1 (976 aa, $108 \mathrm{kDa}$ ) is encoded by the human EPHA1 gene. This protein is involved in tyrosine phosphorylation, ephrin-A binding and the regulation of GT Pase activity. 